\title{
The Development of Computer-Based Career Guidance Application Program for Senior High School Students
}

\author{
Hartono \\ Universitas PGRI Adi Buana \\ Surabaya, Indonesia
}

B Soedarmadji

Universitas PGRI Adi Buana

Surabaya, Indonesia

\begin{abstract}
The purpose of this research is to find a solution to the problem of senior high school students, by developing an application program of computer-based career guidance as a tool to increase the intensity of senior high school students' self-knowledge, careerknowledge, and independence in career choice, which meets three criteria: utility, feasibility, and accuracy. The method of this research is categorized as research of development using a development model that is adapted from Dick and Carey model of which includes three stages: pre-development stage, stage of development, and postdevelopment stage. The results showed that the application program of computer-based career guidance meets the criteria of utility, feasibility, and accuracy with an average score of very good category. Application program development of computer-based career guidance is a positive response to the needs of students and the development of science and technology.
\end{abstract}

Keywords: Career Guidance, Application, Senior High School

\section{INTRODUCTION}

Factors that cause the failure of senior high school students in choosing a career are the lack of ability to self-knowledge and career-knowledge. The failure of students to perform selfknowledge, career-knowledge, and lack of independence in choosing a career adversely affect the process of career education. If this is not addressed, it can lead to unemployment, and unemployment on the other hand will lead to poverty widely influential on social problems such as social unrest, rising crime, and social disparity $[1,10,16]$.

Hartono doing research with 90 students of SMA Negeri 10 Surabaya as samples obtained that there was a significant positive correlation jointly between aspects of self-knowledge, career-knowledge, and the independence aspect in career choice [6]. In 2012, Hartono (2012) also conducted a study on 148 high school students in Surabaya. He found that aspects of self-knowledge and aspects of career-knowledge of students were significantly positively correlated with the intensity of career choice patterns. Senior high school as a formal educational institution in the school track has a very strategic position in shaping the human resources who have high competitiveness $[2,9]$. Usual senior high school students gain adequate educational services, including career guidance services using computer technology as a tool, so that the students are able to choose the right career which matches with their interests, talents, intelligence, personality characteristics, and the environment that in the future they are able to achieve and develop the profession they might achieved.

This study aimed to develop a computer-based career guidance application program as an intelligent solution to help high school students in overcoming difficulties for selfknowledge, career-knowledge, and making career decisions, which have the specification (1) as self-help tool to help high school students (2) in the form of software with a presentation of structured materials and can be on-line, so that high school student users can be more creative in the exploration of a career that is looking for information about colleges of interest (majors/ study program, curriculum, graduate competence, tuition fees, lecture facilities, extracurricular activities, the world of work, prospects, job opportunities after graduation, how to achieve them, constraints and how to overcome these obstacles), (3) containing a self-knowledge program, careerknowledge program, and career decision-making program, (4) the material can be updated, (5) having a manual or operating manual, and (6) the role of counselor as facilitator, mediator, and resource person [4]. Currently in Indonesia there is no a career guidance application program which is implemented to high school students. It needs the development of computerbased career guidance application program that meets the criteria of utility, feasibility, and accuracy, using research development methods as a positive response in the knowledgebased era society [14] characterized by the rapid use of science and technology in performing various career activities in the midst of community life. The application of this program in high school will enable students to achieve independence in choosing a career that is in accordance with its potential, so that they are able to develop their potential to become a generation of nation cadres who have competitive ability to other nations in the world. 


\section{METHOD}

The study was categorized as a research development using a model of development which adapted from the model of Dick and Carey [4] as described in Figure 1as follows.

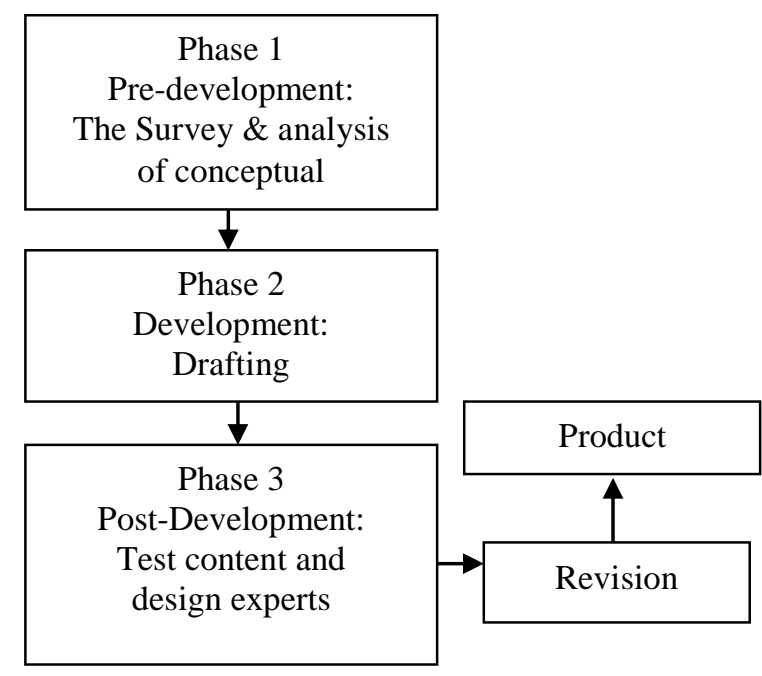

Fig. 1. Model of development adapted from Dick and Carey

Fig 1. The research stages of development consist of three phases: phase 1 pre-development, phase 2 development, and phase 3 post-development. A survey was conducted in predevelopment stage and conceptual analysis of the needs of senior high school students on career guidance services which underlay the need for the development of application programs of computer-based career guidance for senior high school students. Phase 2 is development. This stage performed drafting of career guidance materials, measurement scale (scale of selfknowledge, career-knowledge scale, and scale independence in career choice), software of career guidance, and application guide. Phase 3 is the phase of post-development. At this stage, experts tested the content and design to draft materials, software, and manual application of computer-based career guidance. On the basis of expert test, repairs were conducted to result the product of application program of computer-based career guidance.

Samples (respondent) in this study were determined to be purposive sampling, two content experts, and two design experts. Data were collected using a questionnaire which had been prepared by the researchers based on three criteria: utility, feasibility, and accuracy. Content expert questionnaire which measured the content expert opinion based on the criteria of utility contained 11 statements, based on the feasibility criteria contained 10 statements, and based on the criteria of accuracy contained 10 statements. Questionnaire of design experts which measured the expert opinion based on the criteria of utility contained 11 statements, based on the feasibility criteria contained 11 statements, and based on the criteria of accuracy contained 11 statements.

The data were analyzed with descriptive statistics using current [11]. The percentage of the average score of $0 \%-25 \%$ was categorized as less, $26 \%-50 \%$ was categorized as enough, $51 \%-75 \%$ was categorized as good, and $76 \%-100 \%$ was categorized as very good [4].

\section{RESULTS AND DISCUSSION}

\subsection{Results of research}

The results of content experts and design experts' tests to draft an application program of computer-based career guidance with a scale of 1-4 (1: less; 2 : enough; 3 : good; 4: very good) are outlined in Figure 2 and 3.

According to figure 2 above, the mean score of content experts tests to application program of computer-based career guidance based on the criteria of utility (A) of 3.91 or $97.75 \%$; feasibility criteria (B) of 3.75 or $93.75 \%$; and accuracy criteria (C) of 3.80 or $95 \%$. The average score for the content expert test results based on the criteria of utility, feasibility, and accuracy is 3.82 or $95.5 \%$ in the very good category.

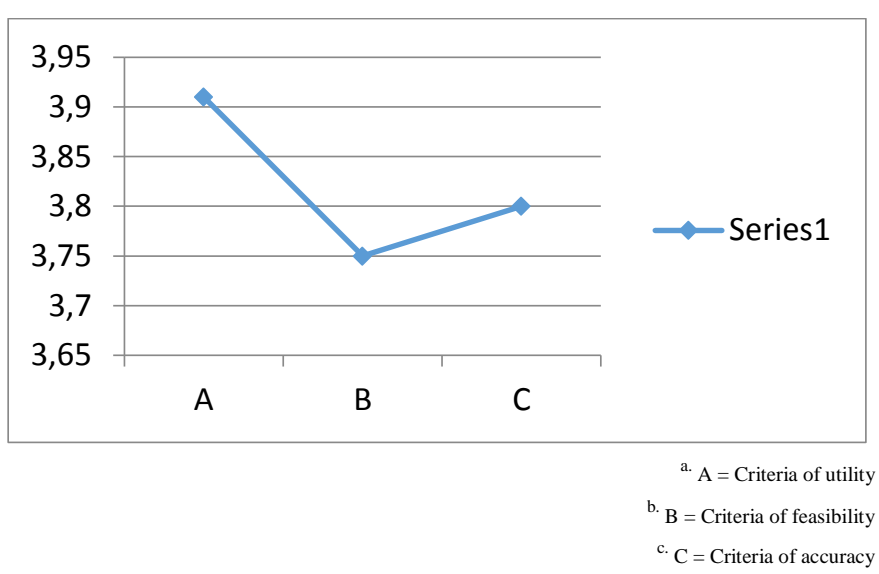

Fig. 2. The mean score on the test result of content expert on application program of computer-based career guidance $(\mathrm{N}=2)$

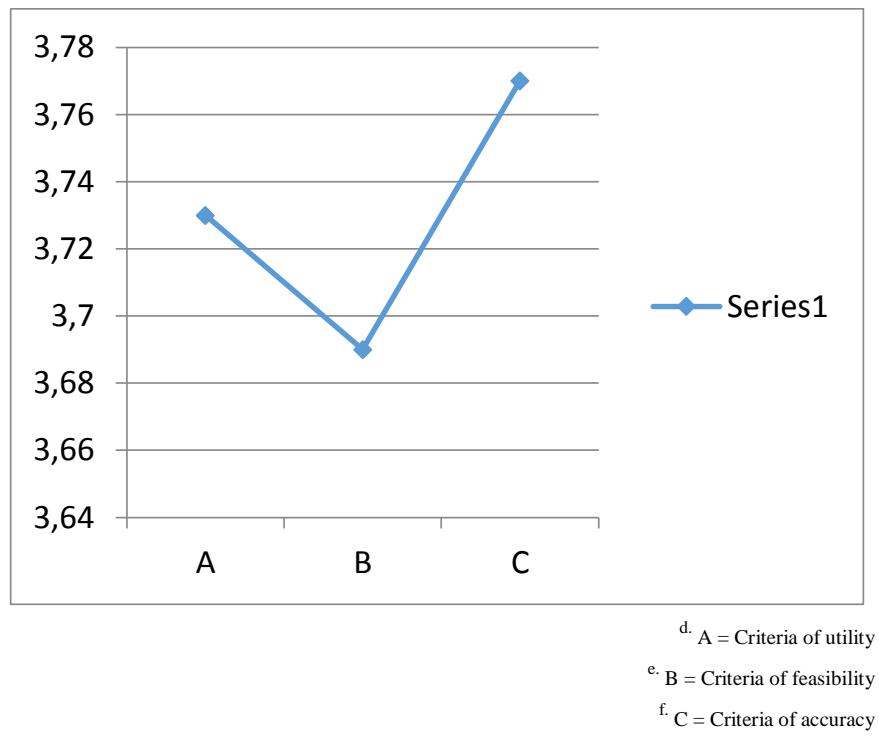

Fig. 3. The mean score on test result of design expert on application program of computer-based career guidance $(\mathrm{N}=2)$ 
According to figure 3 above, the mean score of design experts tests to application program of computer-based career guidance based on the criteria of utility (A) of 3.73 or $93.25 \%$; feasibility criteria (B) of 3.69 or $92.25 \%$; and accuracy criteria (C) of 3.77 or $94.25 \%$. The mean score for the design expert test results based on criteria of utility, feasibility, and accuracy is 3.73 or $93.25 \%$ in the very good category.

\subsection{Discussion}

According to Sharf (2013) the implications of career decision made the theory for counselors varied. Counselors need to apply appropriate approaches for the uniqueness and needs of clients [13]. Cognitive Information Processing Theory (CIP) is a theory of career decision making [7] relating to computerbased career guidance. According to CIP theory, career choices involve four domains: self-knowledge, career-knowledge, decision making, and executive processing. The development of computer-based career guidance application program for high school students is an effort to assist students in improving their independence of career decision making, so that they are able to choose a career field that suits their potential. This developed application program contains three programs: selfknowledge program, career-knowledge program, and career decision-making program.

Self-knowledge and career-knowledge are important requirements in the career decision-making process [12]. The results of Hartono (2010) in senior high school students showed that self-knowledge and career-knowledge are positively correlated, positively significant with the independence of career decision making. The results of Malgwi, Howe, and Burnaby's research in Hartono [13] also showed that student career decisions making were influenced by aspects of selfknowledge and aspects of understanding of career conditions. Aspects of self-knowledge include understanding of interest, ability, personality, self-efficacy, while aspects of understanding of career conditions include salary levels and potential job opportunities. The results of Hirschi and Lage (2008) studies in adolescents showed that career readiness could be significantly improved through career training using self-knowledge module, career-knowledge module, and career decision process module. Study results of Tansley, Jome, Haase, and Martens (2007) indicated that written persuasive messages enhanced college students' career decision-making outcome expectations, intentions, and behaviors.

Based on some research results above, it can be concluded that the development of computer-based career guidance application program for high school students who have met the criteria of utility, feasibility, and accuracy with the average score of the category is very good based on the results of expert test content and design experts, theoretical and empirical, so feasible implemented as a tool for the implementation of career guidance services in senior high schools

\section{CONCLUSION}

Based on the results of the data analysis described above, we can conclude the results of this study as follows.
Development of the application program of computer-based career guidance meets the criteria of utility, feasibility, and accuracy with an average score in very good category. Computer-based career guidance application program as a model of career guidance services in senior high school is a software in career guidance services for high school students, which serve as a tool in an effort to increase independence in choosing a career. It contains three programs: self-knowledge program, career-know-ledge program, and career decisionmaking program. The iImplementation of the application program of computer-based career guidance for senior high school students acts as a form of facilitation to support the career development of students. The role of counselor in the implementation of this program is as facilitator and resource person.

\section{REFERENCES}

[1] A Azalahu, A Ngozi, E John, and AJoseph, "M.U Unemployment and poverty: Implications for national security and good govermance, in Nigeria", in.International Journal o Public Administtration and Management Research, Vol. 2 No. 1, pp 1-11, 2013

[2] Department of Education and Early Childhood Development, Human "resources: Roles and responsibility teaching service, Victoria, http://www.education.vic.gov.au., accessed on 25 September 2014

[3] Depdiknas, Penataan Pendidikan Profesional Konselor dan Layanan Bimbingan dan Konseling dalam Jalur Pendidikan Formal. Jakarta: Depdiknas, 2007

[4] Hartono, Widodo dan Boy Soedarmadji. "Pengembangan Model Bimbingan Karier Berbasis Komputer untuk Meningkatkan Kemandirian dalam Memilih Karier Siswa SMA", Laporan Penelitian Hibah Bersaing Tahun 2014. Surabaya: LP2M Universitas PGRI Adi Buana Surabaya. 2014

[5] Hartono, "Efektivitas bimbingan karier berbantuan komputer terhadap kemandirian pengambilan keputusan karier siswa SMA", in Prosiding Konvensi Nasional XVI ABKIN, 16 November 2009, Surabaya: Unesa University Press, 2010

[6] Hartono, "The correlation between self-knowledge aspect and careerknowledge aspect with the patterns intensity of career choice on senior high school students", in Proceedings The $1^{\text {st }}$ International Seminar on Guidance and Counseling, 8-9 September 2012. Yogyakarta: Study Program of Guidance and Counseling Educational Psychology and Guidance Departement, Faculty of Education, Yogyakarta State University, 2012

[7] Hartono, "Bimbingan Karier”, Jakarta: Kencana Prenada Media Group, 2016

[8] A Hirschi, and D Lage, "Increasing the career choice readiness of young adolescents: An evaluation study", in Int J Educ Vocat Guidance, Vol. 8, pp 95-110, 2008

[9] A Kofoed, and M Olsson, "Learning and development in challenging times", in Human Resource: Management and Training, New York: Unites Nations Economic Commission for Europe, Unites Nations, 2013

[10] M Melrose, "Young people, welfare reform and social insecurity" Youth \& Policy, Vol. 108, 2012. http://www.Youthand-policy.org., accessed on 1 October 2014

[11] J Miles, and P Banyard, Understanding and Using Statistics in Psychology: A Practical Introduction. Los Angeles: Sage Publications Ltd, 2007

[12] R B Mubiana, "Career maturity, career knowledge, and self-knowledge among psychology honours students: An exploratory study", in Dissertation in the Department of Psychology of Faculty of Humanities, Hatfield: University of Pretoria, 2010

[13] R S Sharf, Applying Career Development Theory to Counseling, United Kingdom: Brooks/Cole, 2013 
[14] M C Suciu, et al.," Universities' role in knowledge-based economy and society: Implications for romanian economics higher education", in Amfiteatru Economic, Vol. 8 No. 30, pp 420-436, 2011

[15] D P Tansley, L M Jome, R F Haase, and M P Martens, "The effects of message framing on college students' career decision making”, in Journal of Career Assessment, Vol. 15 No. 3, pp 301-316, 2007
[16] Z Xiuxi, V K G Lim, T S Teo, "The long arm of job insecurity: Its impact on career-specific parenting behaviors and youths' career self-efficacy", in Journal of Vocational Behavior, 2012 (doi:10. 1016/j.jvb.2012.01.018) 